\title{
Topoisomerase-II Inhibitor Racemic XK469
}

National Cancer Institute

\section{Source}

National Cancer Institute. Topoisomerase-II Inhibitor Racemic XK469. NCI Thesaurus. Code C2825.

The racemic form of a synthetic quinoxaline phenoxypropionic acid derivative with antineoplastic properties. XK469R selectively inhibits topoisomerase II by stabilizing the enzyme-DNA intermediates in which topoisomerase subunits are covalently linked to DNA through 5-phosphotyrosyl linkages, thereby interfering with DNA repair and replication, RNA and protein synthesis. This agent possesses unusual solid tumor selectivity and activity against multidrug-resistant cancer cells. XK469R is more water soluble and active than the pure isomers, $\mathrm{R}(+)$ XK469 and S(-)XK469. (NCI05) 